Int. J. Electrochem. Sci., 11 (2016) $9790-9799$

International Journal of

ELECTROCHEMICAL

SCIENCE

WWW.electrochemsci.org

\title{
Electrochemical DNA Sensor for adh 1 Gene Sequence from Corn Endogenous with Carbon Microsphere Modified Electrode
}

Lijun Yan ${ }^{1}$, Xiuli Wang ${ }^{2}$, Guangjiu $\mathrm{Li}^{2}$, Yongxi Lu ${ }^{2}$, Hongwei Gao ${ }^{3}$, Qiutong $\mathrm{Li}^{1}$, Peng $\mathrm{Yi}^{1}$ and Wei Sun ${ }^{1, *}$

${ }^{1}$ Key Laboratory of Tropical Medicinal Plant Chemistry of Ministry of Education, College of Chemistry and Chemical Engineering, Hainan Normal University, Haikou 571158, P. R. China

${ }^{2}$ College of Chemistry and Molecular Engineering, Qingdao University of Science and Technology, Qingdao 266042, China

${ }^{3}$ Shandong Entry-Exit Inspection and Quarantine Bureau, Qingdao 266001, China

*E-mail: swyy26@ hotmail.com

doi: $10.20964 / 2016.12 .59$

Received: 6 September 2016 / Accepted: 12 October 2016 / Published: 10 November 2016

In this paper carbon sphere (CS) and chitosan (CTS) were used to modify carbon ionic liquid electrode (CILE). Then CTS-CS/CILE was further used to immobilize probe single-stranded DNA (ssDNA) sequence to get an electrochemical DNA sensor. The presence of CS provides a big surface area and CTS exhibits strong electrostatic affinity to the negatively charged ssDNA, therefore oligonucleotides probe sequence could be fixed on CTS-CS/CILE tightly. Target adh 1 ssDNA sequence from corn endogenous in the solution was measured by this electrochemical sensor with methylene blue (MB) as the hybridization indicator, which could distinguish ssDNA and dsDNA on the electrode surface. At the optimal conditions the reduction current of $\mathrm{MB}$ had a linear relationship with adh 1 gene sequence concentration from $1 \times 10^{-13}$ to $1.0 \times 10^{-6} \mathrm{~mol} \mathrm{~L}^{-1}$ with the detection limit as $6.42 \times 10^{-14} \mathrm{~mol} \mathrm{~L}^{-1}(3 \sigma)$. This electrochemical DNA sensor could discriminate different mismatched ssDNA sequences, and further applied to the detection of polymerase chain reaction amplification product of adh 1 gene sequences of corn endogenous from edible oil.

Keywords: Carbon sphere; chitosan; electrochemical DNA biosenor; carbon ionic liquid electrode; adh 1 gene.

\section{FULL TEXT}


(C) 2016 The Authors. Published by ESG (www.electrochemsci.org). This article is an open access article distributed under the terms and conditions of the Creative Commons Attribution license (http://creativecommons.org/licenses/by/4.0/). 